\section{'Charleston Nemagreen', a Root-knot Nematode Resistant, Cream-type Southernpea with a Green Cotyledon Phenotype}

\author{
Richard L. Fery ${ }^{1}$ and Judy A. Thies ${ }^{2}$ \\ U.S. Vegetable Laboratory, Agricultural Research Service, U.S. Department \\ of Agriculture, 2875 Savannah Highway, Charleston, SC 29414-5334
}

Additional index words. Vigna unguiculata, cowpea, soil-borne pathogen, Meloidogyne, disease resistance, vegetable breeding

'Charleston Nemagreen' is a new southernpea [Vigna unguiculata (L.) Walp.] released on 1 Aug. 2001 by the U.S. Dept. of Agriculture, Agricultural Research Service. 'Charleston Nemagreen' is the first greencotyledon phenotype southernpea to be released with resistance to root-knot nematodes (Meloidogyne sp.). The new cultivar is well adapted for production throughout the southeastern United States, and can be expected to produce excellent yields of cream-type southernpeas. 'Charleston Nemagreen' is recommended for use by the frozen food industry and home gardeners.

\section{Origin}

'Charleston Nemagreen' was developed over a 10-year period using a pedigree breeding procedure that included a single cross and repeated single-plant selections (Fig. 1). The original cross involved 'Bettergreen', a creamtype cultivar with green-colored cotyledons, and US-629, a cream-type breeding line with cream-color cotyledons. 'Bettergreen', which originated as a pure-line selection of a green cotyledon mutant from a population of 'Carolina Cream' plants, is susceptible to root-knot nematodes (Fery and Dukes, 1984; Fery et al., 1993). US-629 is the product of a recurrent backcross breeding program (six backcrosses) to incorporate the $R k$ root-knot nematode resistance gene (Fery and Dukes, 1980) into a 'Carolina Cream' background. After the initial cross, intense selection pressure was applied in subsequent segregating generations horticultural characteristics. 'Charleston

'Floricream'

\section{Description}

The plant and maturity characteristics of 'Charleston Nemagreen' are quite similar to those of 'Bettergreen'. 'Charleston Nemagreen' has a medium, bushy growth habit and produces dry pods at Charleston, S.C., in 64 to $72 \mathrm{~d}$ (Fig. 2, Tables 1 and 2). Flower color is white. There is no red or purple pigmentation on the stems, branches, petioles, or peduncles. 'Charleston Nemagreen' has a dark green foliage color. Pod set is concentrated, and the pods are borne at foliage level in a scattered fashion. Dry pods are attached to the peduncles in a pendant fashion. Each peduncle typically produces two pods.

A typical 'Charleston Nemagreen' pod is slightly curved, $16 \mathrm{~cm}$ long, and contains 15 peas (Fig. 3). Pod color is green when immature, green with a distinct purple shading at optimum green-shell maturity, and light straw color when dry. Fresh peas have an ovate to reniform shape. Dry 'Charleston Nemagreen' peas have a smooth seedcoat and are slightly smaller in size than 'Bettergreen' peas (weight per 100 dry peas: 'Charleston Nemagreen', $9.8 \mathrm{~g}$; 'Bettergreen', $10.0 \mathrm{~g}$ ).

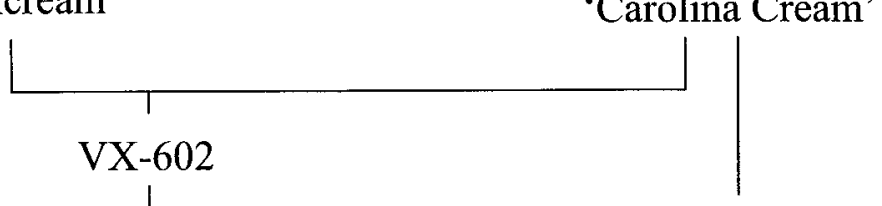
(Fery and Dukes, 1994). Seedcoats and cotyledons of field-grown 'Charleston Nemagreen' peas harvested at the dry-stage of maturity are light olive in color, whereas those of 'Carolina Cream' peas harvested at a similar stage of maturity are a cream color. Dry 'Charleston Nemagreen' peas imbibed to restore freshharvest seed size and blanched in boiling water for 3 min exhibit a near-fresh green color. None of the 'Charleston Nemagreen' peas soaked in water during the imbibition process exhibited the hard-seed trait common in some southernpea cultivars.

'Charleston Nemagreen' is homozygous for the $R k$ gene that conditions resistance to the southern root-knot nematode $[M$. incognita (Kofoid and White) Chitwood], the Javanese root-knot nematode $[M$. javanica (Treub.) Chitwood], and the northern root-knot nematode [M. hapla Chitwood] (Fery and Dukes, 1980). Isolates of $M$. incognita race 3 were used to bioassay for the presence of the $R k$ gene during the development of 'Charleston Nemagreen', and the results of all greenhouse tests indicated that the resistance exhibited by 'Charleston Nemagreen' is equal to the resistance exhibited by the widely grown crowder-

\section{'Carolina Cream'}

The results of 4 years (1997-2000) of replicated field testing at Charleston, S.C., indicate that the yield potential of "Charleston Nemagreen' is similar to that of 'Bettergreen' (the 'Charleston Nemagreen' yield of dry peas over the entire 4-year period of replicated testing was $101 \%$ of the yield of 'Bettergreen') (Table 2). 'Charleston Nemagreen' was tested as US-910 throughout the southern United States as an observational entry in the 1998 Regional Southernpea Cooperative Trials and as a replicated entry in the 1999 and 2000 trials. During the three years of testing in these trials, the yield of 'Charleston Nemagreen' peas was $105 \%$ of the yield of the cream-type control ('Early Acre').

'Charleston Nemagreen', like its 'Bettergreen' parent, is homozygous for the $g c$ gene that conditions the green cotyledon trait for combined green cotyledon and root-knot nematode resistant phenotypes and superior Nemagreen' originated as a bulk of an $\mathrm{F}_{8}$ line grown in 1996.

Received for publication 7 Jan. 2002. Accepted for publication 25 Mar. 2002. The technical assistance of F.P. Maguire and E.L. Corley is gratefully acknowledged.

${ }^{1}$ Research Geneticist.

${ }^{2}$ Research Plant Pathologist.

Six successive backcrosses

to 'Carolina Cream' to

incorporate $R k$ root-knot resistance

gene from 'Floricream'

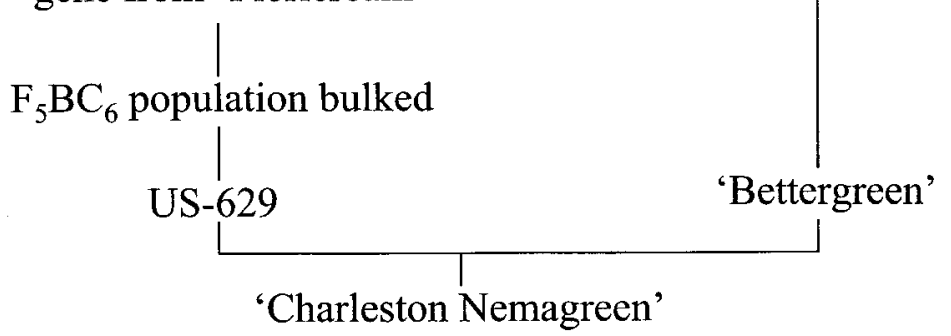

Fig. 1. Pedigree of 'Charleston Nemagreen' southernpea.

Pure line selection of a green cotyledon mutant 


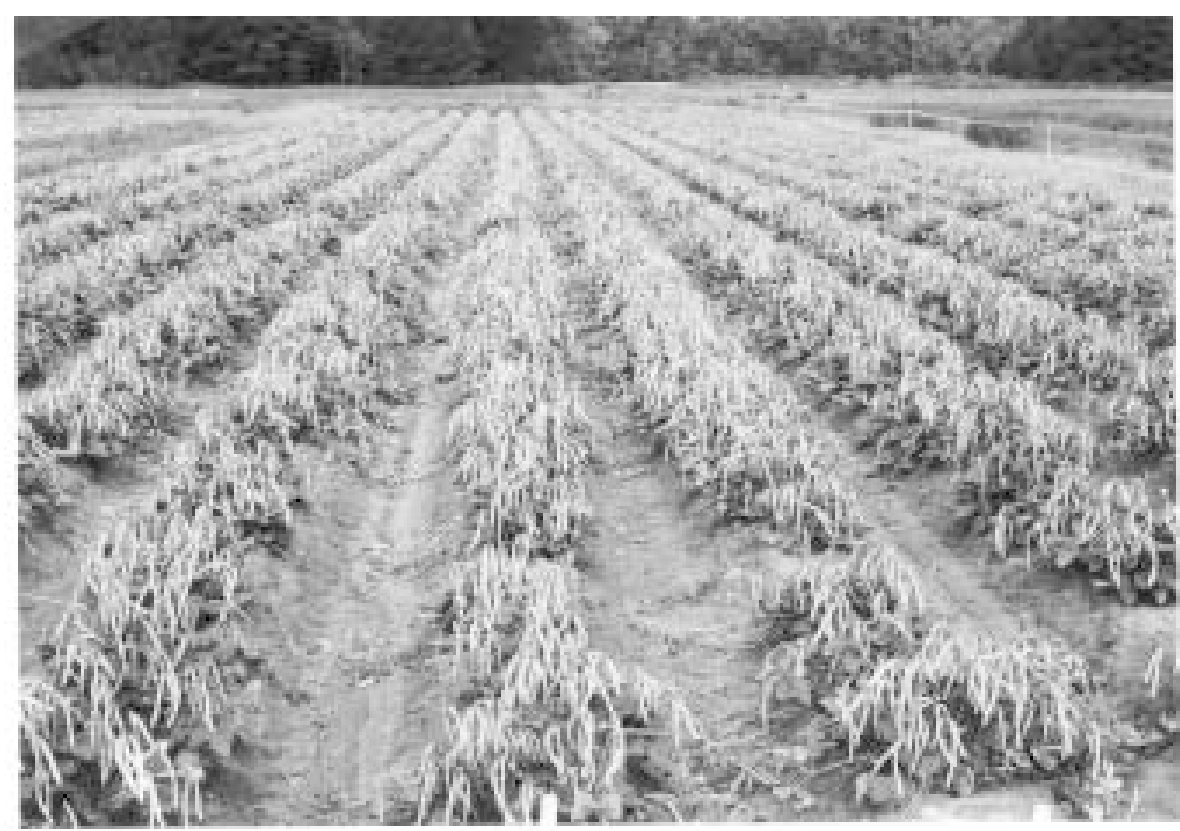

Fig. 2. Spaced-planted field (single-plants spaced $90 \mathrm{~cm}$ apart on beds $102 \mathrm{~cm}$ apart) of "Charleston Nemagreen' southernpea.

Table 1. Plant height, plant width, peduncle length, pod length, and number of peas per pod for 'Charleston Nemagreen' and 'Bettergreen' southernpeas, Charleston, S.C., $2000 .^{z}$

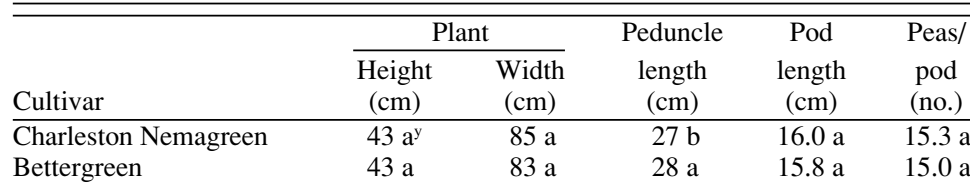

${ }^{2}$ Trial planted on 1 June 2000 . The experimental design was a randomized complete block with 10 replications. Each plot was space-planted, 18 hills per plot, three seeds per hill, $30 \mathrm{~cm}$ between hills, and $102 \mathrm{~cm}$ between rows.

${ }^{y}$ Mean separation within columns by Student-Newman-Keuls multiple range test, $P \leq$ 0.05 .

Table 2. Number of days to harvest, weight per 100 dry peas, and dry pea yield for 'Charleston Nemagreen' and 'Bettergreen' southernpeas grown in spring trials, Charleston, S.C., 1997-2000. ${ }^{2}$

\begin{tabular}{|c|c|c|c|}
\hline Cultivar & $\begin{array}{c}\text { Days to } \\
\text { harvest } \\
\text { (no.) }\end{array}$ & $\begin{array}{c}\mathrm{Wt} / 100 \\
\text { dry peas } \\
(\mathrm{g})\end{array}$ & $\begin{array}{c}\text { Dry pea } \\
\text { yield } \\
\left(\mathrm{kg} \cdot \mathrm{ha}^{-1}\right)\end{array}$ \\
\hline \multicolumn{4}{|c|}{ Trial $1-1997$} \\
\hline Charleston Nemagreen & $72.2 \mathrm{a}^{y}$ & $9.7 \mathrm{a}$ & $1269 \mathrm{a}$ \\
\hline Bettergreen & $72.0 \mathrm{a}$ & $9.9 \mathrm{a}$ & $1058 \mathrm{~b}$ \\
\hline \multicolumn{4}{|c|}{ Trial II - 1998} \\
\hline Charleston Nemagreen & $68.0 \mathrm{a}$ & $10.1 \mathrm{a}$ & $1285 \mathrm{a}$ \\
\hline Bettergreen & $68.0 \mathrm{a}$ & $10.2 \mathrm{a}$ & $1298 \mathrm{a}$ \\
\hline \multicolumn{4}{|c|}{ Trial III - 1999} \\
\hline Charleston Nemagreen & $64.2 \mathrm{a}$ & $7.8 \mathrm{a}$ & $811 \mathrm{a}$ \\
\hline Bettergreen & $63.4 \mathrm{a}$ & $7.7 \mathrm{a}$ & 816 a \\
\hline \multicolumn{4}{|c|}{ Trial IV -2000} \\
\hline Charleston Nemagreen & $70.4 \mathrm{a}$ & $11.7 \mathrm{a}$ & $1016 \mathrm{a}$ \\
\hline Bettergreen & $69.2 \mathrm{a}$ & $12.1 \mathrm{~b}$ & $1162 \mathrm{a}$ \\
\hline \multicolumn{4}{|c|}{ Combined analysis of all trials } \\
\hline Charleston Nemagreen & $68.7 \mathrm{a}^{\mathrm{Ns}}$ & $9.8 \mathrm{~b}^{\mathrm{Ns}}$ & $1095 \mathrm{a}^{*}$ \\
\hline Bettergreen & $68.2 \mathrm{a}$ & $10.0 \mathrm{a}$ & $1083 \mathrm{a}$ \\
\hline \multicolumn{4}{|c|}{ 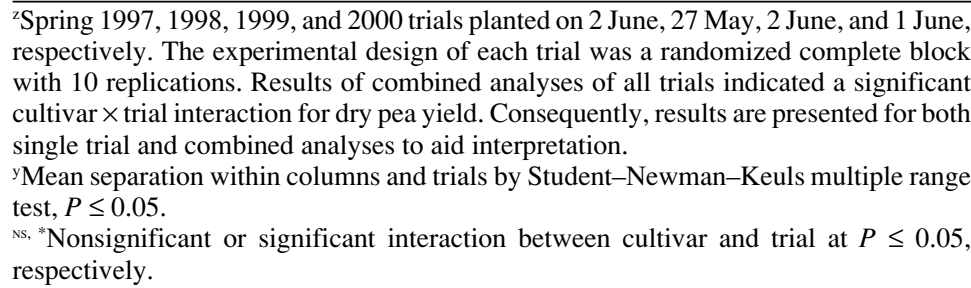 } \\
\hline
\end{tabular}

type cultivar Mississippi Silver. The numbers of galls and egg masses on the roots were always minimal (Fig. 4). The results of a 1999 replicated test conducted in a soil-filled greenhouse bench infested with $M$. incognita (each seed inoculated with $\approx 2700 \mathrm{M}$. incognita race 3 eggs at planting) showed that fresh 'Charleston Nemagreen' roots yielded $95 \%$ fewer $M$. incognita eggs/gram than did fresh 'Bettergreen' roots (Table 3).

An examination of the pedigree of 'Charleston Nemagreen' demonstrates that the new cultivar is very closely related (near isogenic) to both 'Carolina Cream' and 'Bettergreen'. As such, 'Charleston Nemagreen' should be expected to exhibit the same resistances to the cowpea curculio [Chalcodermus aeneus Boehman], Cercospora leaf spot (Cercospora cruenta Sacc.), rust [Uromyces phaseoli (Pers.) Wint. var. vignae (Barcl.) Arth.], southern blight [Sclerotium rolfsii Sacc.], and powdery mildew [Erysiphe polygoni DC.ex St. Amans], and the same field tolerances to seedling diseases and blackeye cowpea mosaic virus as these cultivars. The results of a test conducted by Fery and Dukes (1996) in a field infested with a natural population of $M$. incognita demonstrated the value of the $R k$ root-knot nematode resistance gene in a 'Carolina Cream' background. Fery and Dukes (1996) reported that a resistant isoline of 'Carolina Cream' ('Tender Cream') outyielded the susceptible 'Carolina Cream' by $22.4 \%$.

'Charleston Nemagreen' is recommended for use by the frozen food industry and home gardeners. The frozen food industry can imbibe dry peas in water and use the resulting raw product to produce a pack that closely approximates the color and appearance of fresh peas. Home gardeners can harvest peas fresh for immediate consumption or storage in home freezers. 'Charleston Nemagreen' has potential for use by commercial vegetable growers as a root-knot nematode resistant rotation crop for managing root-knot nematodes in soils used for production of susceptible cultivars of other vegetable crops. 'Charleston Nemagreen' should be particularly useful for home gardeners, who often do not have easy access to needed nematicides or garden sites not infested with root-knot nematodes. 'Charleston Nemagreen' should perform well in all areas where 'Bettergreen' has been grown successfully.

\section{Availability}

Breeder's seed of 'Charleston Nemagreen' has been released to seed producers. Small samples of 'Charleston Nemagreen' breeder's seed are available from the senior author for distribution to interested research personnel. Genetic material of this release will be deposited in the National Plant Germplasm System where it will be available for research purposes, including the development and commercialization of new cultivars. It is requested that appropriate recognition of source be given when this germplasm contributes to research or development of a new breeding line or cultivar. 


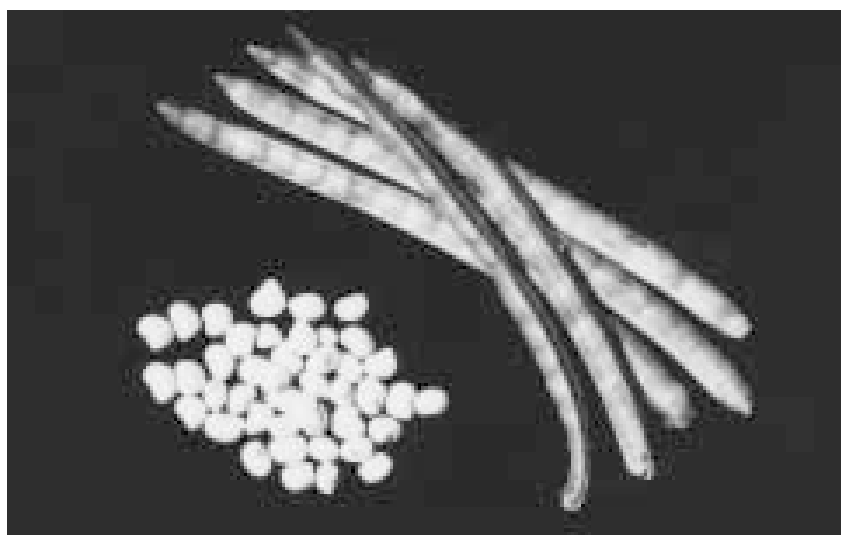

\section{Literature Cited}

Fery, R.L. and P.D. Dukes. 1980. Inheritance of root-knot nematode resistance in cowpea [Vigna unguiculata (L.) Walp.]. J. Amer. Soc. Hort. Sci. 105:671-674.

Fery, R.L. and P.D. Dukes. 1984. 'Carolina Cream' southernpea. HortScience 19:456-457.

Fery, R.L. and P.D. Dukes. 1994. Genetic analysis of the green cotyledon trait in southernpea [Vigna unguiculata (L.) Walp.]. J. Amer. Soc. Hort. Sci. 119:1054-1056.

Fery, R.L. and P.D. Dukes. 1996. 'Tender Cream' southernpea. HortScience 31:1250-1251.

Fery, R.L., P.D. Dukes, and F.P. Maguire. 1993 'Bettergreen' southernpea. HortScience 28:856.

Hussey, R.S. and K.R. Barker. 1973. A comparison of methods of collecting inocula of Meloidogyne spp., including a new technique. Plant Dis. Rptr. 57:1025-1028.

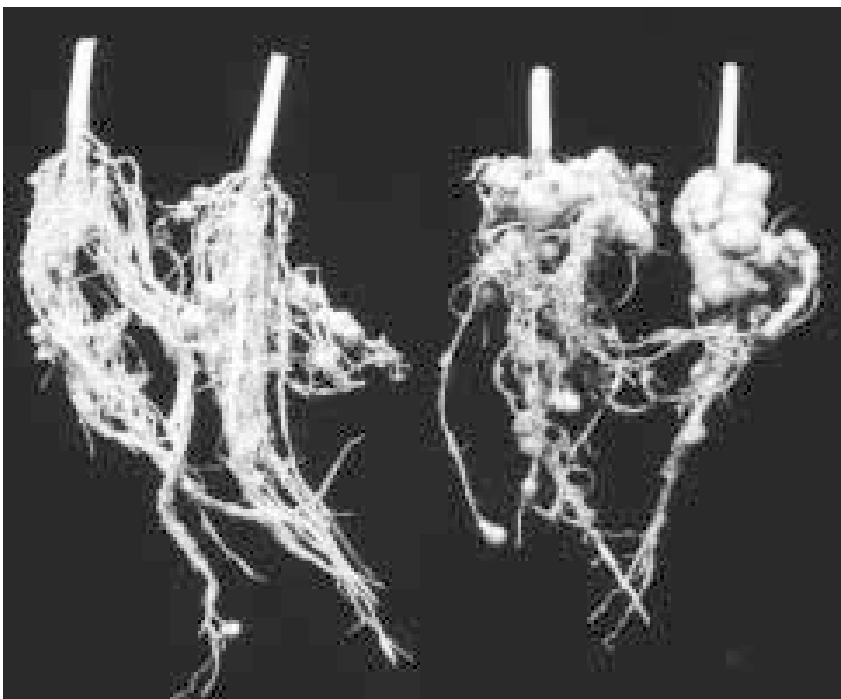

Fig. 4. Examples of roots removed from a soil-filled greenhouse bench infested with southern root-knot nematodes (Meloidogyne incognita race 3). The root systems of the two plants on the left are from the resistant cultivar Charleston Nemagreen and those on the right from the susceptible cultivar Bettergreen. Note the absence of galling (and presence of nodules) on the healthy 'Charleston Nemagreen' root systems and the presence of severe galling on 'Bettergreen' root systems.

Table 3. Average root-gall index, average egg mass index, and average number of eggs per gram fresh root tissue for 'Charleston Nemagreen', 'Bettergreen', 'Mississippi Silver', and 'Pinkeye Purple Hull-BVR' plants grown in soil infested with the southern root-knot nematode, Meloidogyne incognita race 3 (Greenhouse Experiment). ${ }^{\mathrm{z}}$

\begin{tabular}{llcr}
\hline \hline Cultivar & $\begin{array}{c}\text { Gall } \\
\text { index }^{\mathrm{y}}\end{array}$ & $\begin{array}{c}\text { Egg } \\
\text { mass }_{\text {index }}^{\mathrm{x}}\end{array}$ & $\begin{array}{c}\text { No. eggs/g } \\
\text { fresh root } \\
\text { tissue }\end{array}$ \\
\hline Charleston Nemagreen & $1.22 \mathrm{c}^{\mathrm{w}}$ & $1.10 \mathrm{~b}$ & $6,151 \mathrm{~b}$ \\
Bettergreen $^{\mathrm{w}}$ & $5.00 \mathrm{a}$ & $5.00 \mathrm{a}$ & $124,080 \mathrm{a}$ \\
Mississippi Silver $^{\mathrm{v}}$ & $1.33 \mathrm{c}$ & $1.10 \mathrm{~b}$ & $6,993 \mathrm{~b}$ \\
Pinkeye Purple Hull-BVR $^{\mathrm{u}}$ & $4.85 \mathrm{~b}$ & $4.97 \mathrm{a}$ & $85,312 \mathrm{a}$
\end{tabular}

${ }^{2}$ Randomized complete-block experiment with six replications (five plants per plot; seeds sowed in a steam-pasteurized mixture of soil, sand, and peat on 25 Feb. 1999; each seed inoculated with $\approx 2700 \mathrm{M}$. incognita race 3 eggs at sowing; roots of all plants evaluated for galling and egg masses on 1 June 1999). The NaOCl procedure described by Hussey and Barker (1973) was used to extract $M$. incognita eggs from a fibrous root sample taken from each plot. ${ }^{y}$ Rated on a scale of 1 to $5: 1=$ no galls; $2=$ light galling, $1 \%$ to $25 \%$ of root system galled; 3 $=$ moderate galling, $26 \%$ to $50 \%$ of root system galled; $4=$ heavy galling, $51 \%$ to $80 \%$ of root system galled; and $5=$ severe galling, $81 \%$ to $100 \%$ of root system galled.

${ }^{x}$ Rated on a scale of 1 to $5: 1=$ no egg masses evident, $2=$ scattered egg masses covering $1 \%$ to $25 \%$ of root system, $3=$ moderate number of egg masses covering $26 \%$ to $50 \%$ of root system, $4=$ numerous egg masses covering $51 \%$ to $80 \%$ of root system, and $5=$ extremely large number of egg masses covering $81 \%$ to $100 \%$ of root system.

"Mean separation within columns by Student-Newman-Keuls multiple range test, $P \leq 0.05$.

${ }^{\vee}$ Resistant control.

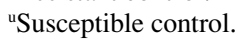

